\title{
Juglans Regia Extract (JRE) as Eco-Friendly Inhibitor for Aluminum Metal in Hydrochloric Acid Medium
}

\author{
Abd El-Aziz S. Fouda 1, * (D), Salah M. Rashwan ${ }^{2}$, Medhat M. Kamel ${ }^{2}$, Eslam Abdel Haleem ${ }^{1,3}$ \\ Department of Chemistry, Faculty of Science, El-Mansoura University, Egypt \\ Department of Chemistry, Faculty of Science, Suez Canal University, Egypt \\ Department of Basic Science, Higher Institute of Engineering and Technology in El-Arish, Egypt \\ * Correspondence: asfouda@ @otmail.com;
}

Scopus Author ID 56231506400

Received: 18.04.2020; Revised: 7.05.2020; Accepted: 8.05.2020; Published: 13.05.2020

\begin{abstract}
The consumption impact of aluminum in the corrosive medium $(2 \mathrm{M} \mathrm{HCl})$ in the existence of JRE has been contemplated utilizing, electrochemical impedance spectroscopy (EIS), electrochemical frequency modulation (EFM), potentiodynamic polarization (PP), mass loss and gasometry methods. The impact of EIS displayed the expansion in the polarization resistance $\left(\mathrm{R}_{\mathrm{p}}\right)$ and the decline in the double layer capacitance $\left(\mathrm{C}_{\mathrm{dl}}\right)$. Polarization demonstrated that JRE goes about as inhibitor of mixed-type. \%IE has been seen as various with a concentration of Juglans Regia concentrate and temperature. The adsorption of JRE on the outside of $\mathrm{Al}$ from the damaging corrosive medium obeys Langmuir isotherm. All thermodynamic calculations of Al consumption were settled and talked about. The AFM examination of the Al surface indicated that the concentrate avoided consumption by adsorption on its surfaces and diminished the roughness. FTIR outcomes demonstrated the presence of many functional groups by which the adsorption process occurs. The XPS examination affirmed the arrangement of a defensive layer of JRE on the Al surface. Results got demonstrated great harmony which confirms the potential utilization of JRE to inhibit the dissolution of aluminum in the corrosive medium.
\end{abstract}

Keywords: Gasometry; EIS; EFM; XPS; Langmuir isotherm.

(C) 2020 by the authors. This article is an open access article distributed under the terms and conditions of the Creative Commons Attribution (CC BY) license (https://creativecommons.org/licenses/by/4.0/).

\section{Introduction}

Al has an economic and mechanical significance because of perfect electrical and thermal conductivity. Inhibition of Al against dissolution in corrosive medium related to a quickly shaped conservative, emphatically disciple and continued oxide membrane $[1,2]$. Accordingly, Al and its derivatives are generally utilized in numerous ventures, for example, response vessels, channels, apparatus and compound batteries. Hydrochloric corrosive arrangements are utilized for pickling, substance and electrochemical carving of Al [3]. Additionally, the nearness of forceful particles like $\mathrm{Cl}^{-}$ions makes broad localizing attack [4]. In view of the general forceful corrosive arrangements, inhibitors are ordinarily used to lessen the destructive assault on metallic substances. A large portion of the consumption inhibitors is manufactured substances that are dangerous, costly and non-biodegradable. Consequently, it is essential to search for eco-friendly secure inhibitors [5-10]. Green extracts became significant in light of the fact that they are naturally worthy, promptly accessible and sustainable source of required materials. Green extracts are seen as an unimaginably rich of chemical substances which naturally synthesized that can be extracted by basic methodology with minimal effort. 
These products were recently utilized as consumption inhibitors for various metals in different conditions [11-23] and their ideal concentrations were accounted. The acquired information demonstrated that plant extract could fill in as successful consumption inhibitors.

The point of this assessment was to investigate the inhibitor impact of (JRE) as green effective inhibitor for $\mathrm{Al}$ in $2 \mathrm{M} \mathrm{HCl}$ using chemical, electrochemical and surface morphology investigations. The effect of the temperature on the rate of consumption and thermodynamic parameters was resolved.

\section{Materials and Methods}

\subsection{Composition of Aluminum samples.}

$\mathrm{Al}$ pieces utilized for this study were taken from $\mathrm{Al}$ with a pureness of $99.98 \%$.The specimens with dimensions $2 \times 2 \times 0.5 \mathrm{~cm}$.

\subsection{Solutions and Materials}

Examinations were done utilizing $\mathrm{Al}$ pieces $1 \mathrm{~cm}^{2}$ as a working electrode, an epoxy gum was utilized to occupy the space among Teflon and Al cathode. The auxiliary anode was a platinum sheet $\left(1 \mathrm{~cm}^{2}\right)$, reference electrode acts as saturated calomel cathode (SCE) was connected to a customary electrolytic cell by means of a bridge with a Luggin fine, the tip was exceptionally near the outside of the working electrode to limit the IR drop. The corrosive medium utilized was set up by dilution of $34 \% \mathrm{HCl}$ with bi-distilled water. The stock concentration (1000 ppm) of (JRE) was utilized to set up the wanted concentrations by the addition of bi-distilled water. The concentration extent was (50-300) ppm. The major chemical substances of (JRE) are caffeic acid, germacrene B, Isocaryophyllene and $\alpha$-Pinene [24, 25].

\subsection{Preparation of plant Extract.}

The leaves (Fig.1) were left dried for $10-15$ days at $25^{\circ} \mathrm{C}$ and converted to a fine powder in a blender processor. 200 gram powdered example was extracted with methanol $70 \%$ for 48 . The concentrate was separated utilizing filtering paper. The dissolvable was removed totally under Rotating vaccum. The dried residues were disintegrated in $3 \mathrm{ml}$ of Di methyl sulfoxide (DMSO) and completed to 1 liter utilizing ethanol and lastly stocked under cooling in glass flasks. The main components present in JRE are presented in table 1.

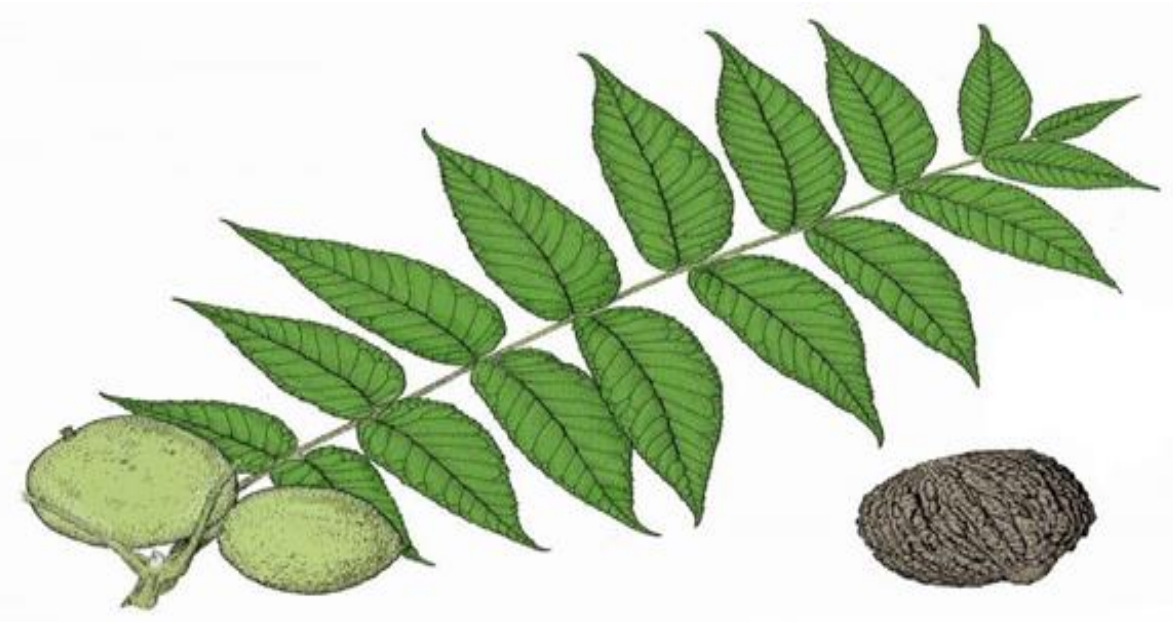

Fig. 1. Juglans Regia plant. 
Table 1. The chemical components exist in Juglans Regia extract.

\begin{tabular}{|c|c|c|}
\hline Name & Strucure & $\begin{array}{l}\text { Molecular } \\
\text { Formula }\end{array}$ \\
\hline caffeic acid & & $\mathrm{C}_{9} \mathrm{H}_{8} \mathrm{O}_{4}$ \\
\hline $\begin{array}{l}\text { germacrene } \\
\text { B }\end{array}$ & -8-Isopropylidene-1,5-dimethyl-1,5-cyclodecadiene & $\mathrm{C}_{15} \mathrm{H}_{24}$ \\
\hline $\begin{array}{l}\text { Isocaryophyl } \\
\text { lene }\end{array}$ & $-4,11,11-$ Trimethyl-8-methylenebicyclo[7.2.0]undec-4-ene & $\mathrm{C}_{15} \mathrm{H}_{24}$ \\
\hline$\alpha$-Pinene & 2,6,6-Trimethylbicyclo[3.1.1]hept-2-en & $\mathrm{C}_{10} \mathrm{H}_{16}$ \\
\hline
\end{tabular}

\subsection{Methods used for corrosion calculations.}

\subsubsection{Potentiodynamic polarization method.}

A polarization investigation was performed in a customary cell of three electrodes. Platinum sheet acts as the auxiliary electrode $\left(1 \mathrm{~cm}^{2}\right)$ and a saturated calomel electrode (SCE) as a reference electrode. The working anode was as a square cut from $\mathrm{Al}$ sheet of equivalent structure implanted in epoxy layer of poly tetra fluoro ethylene to make the area is about $1 \mathrm{~cm}^{2}$. Prior calculations, the electrodes were submerged in a medium at regular potential for half hour to reach the steady state. The potential was begun from -600 to $+400 \mathrm{mV}$ versus open circuit potential. The examinations were completed in various concentrations at $25^{\circ} \mathrm{C}$. The outcomes were constantly repeated in any event multiple times to check the reproducibility. The level of surface coverage $(\theta)$ and $\%$ IE were determined from eq. (1):

$$
\% \text { IE }=\theta \times 100=\left[\left(i_{\text {corr }}-i_{\text {corr }(\text { inh })}\right) / i_{\text {corr }}\right] \times 100
$$

Where $\mathrm{i}_{\text {corr(Inh) }}$ and $\mathrm{i}_{\text {corr }}$ are the inhibited and uninhibited corrosion current density.

\subsubsection{Electrochemical impedance spectroscopy method (EIS).}

The experimental impedances were performed and explained based on the equivalent circuit. All fundamental parameters found from the examination of the nyquist graph are the polarization resistance $R_{p}$ and the double layer capacitance $C_{\mathrm{dl}}[26]$ which is characterized as:

$$
\mathrm{C}_{\mathrm{dl}}=1 /\left(2 \pi \boldsymbol{f}_{\max } \mathrm{R}_{\mathrm{P}}\right)
$$

Where $f \max$ is the angular frequency. \% IE got from the estimations is characterized by the accompanying relationships:

$$
\% \mathrm{IE}=\left[1-\left(\mathrm{R}^{\circ} \mathrm{P} / \mathrm{R}_{\mathrm{P}}\right)\right] \times 100
$$

Where $\mathrm{R}_{\mathrm{p}}^{\mathrm{o}}$ and $\mathrm{R}_{\mathrm{p}}$ are the polarization resistance without and with the inhibitor, respectively 


\subsubsection{Electrochemical frequency modulation technique (EFM).}

EFM was done utilizing two frequencies 2 and $5 \mathrm{~Hz}$. The principle frequency is $0.1 \mathrm{~Hz}$, Thus the wave duplicates every $1 \mathrm{sec}$. The spectrum includes current reactions alloted for consistent and intermodulation flow tops. The major peaks were applied to calculate the current of corrosion (icorr), the causality factors (CF2 and CF3) and the Tafel slopes ( $\beta \mathrm{a}$ and $\beta \mathrm{c}$ ) $[27,28]$.

\subsubsection{Mass Loss Method.}

The mass loss measurements were done utilizing Al samples of volume $2 \times 2 \times 0.5 \mathrm{~cm}$. The samples were first scraped to a mirror with (400, 600 and 1000) coarseness emery sheet, submerged in acetone and lastly washed and get dried before being measured and dipped in the corrosive medium. The mass loss estimations were completed in a $100 \mathrm{ml}$ limit glass beaker set in water thermostat, which has $100 \mathrm{ml}$ of $2 \mathrm{M} \mathrm{HCl}$ with expansion of various concentrations of (JRE). The experiments that occurred were available to air. Following 3 hours immersion the samples were removed, washed, dehydrated, and weighed exactly. The normal mass loss of all Al sheets could be acquired. The degree of surface coverage $(\theta)$ and $\%$ IE of (JRE) for the consumption of $\mathrm{Al}$ was determined as follows:

$$
\% \mathrm{IE}=\theta \times 100=\left[\left(\mathrm{W}^{\mathrm{o}}-\mathrm{W}\right) / \mathrm{W}^{\mathrm{o}}\right] \times 100
$$

Where $\mathrm{W}$ and $\mathrm{W}^{0}$ are the estimations of the mass losses in the existence and absence of the inhibitor, separately

\subsubsection{Gasometry.}

The evolution of hydrogen is a helpful method that computes the volume of hydrogen creating during a corrosion procedure. The applied vial must approach through a plastic roller to a burette. At first, the air quantity was rated. At last, Al sheets were dipped in the corrosive medium and the experimental bottle was inclosed. The degree of $\mathrm{H}_{2}$ volume was evaluated by the diminishing of the solution grade in the burette at constant time interims.

2.4.6. Atomic force microscopy (AFM) analysis.

The preferred feature of AFM is that the outer surface roughness can be found out which is a proportion of the metal surface. The surface roughness is caused due to deviations of a surface from its ideal shape.

2.4.7. Fourier-transform infrared (FTIR) check.

FTIR spectrum was listed in a Perkin - Elmer 1600 spectrophotometer. The membrane was painstakingly expelled, mixed completely with $\mathrm{KBr}$ formed into spherule and FTIR spectrum was listed.

2.4.8. X-Ray photoelectron spectroscopy (XPS) examination.

XPS technique acquires deep knowledge about the idea of the interference between the metal surface and the desired inhibitor. 


\section{Results and Discussion}

\subsection{Potentiodynamic polarization method.}

The polarization bends for $\mathrm{Al}$ in corrosive solutions containing various concentrations of (JRE) at $25 \pm 1 \mathrm{C}^{0}$ are appeared in Fig. 2. The consumption kinetic parameters, for example, corrosion current ( $\left.i_{c o r r}\right)$, corrosion potential ( $E_{c o r r}$ ), and Tafel slopes $\beta_{a}$ and $\beta_{c}$ got from the figure are given in Table 2 for $\mathrm{Al}$ in $2 \mathrm{M} \mathrm{HCl}$ corrosive medium in the nonappearance and nearness of changed concentrations of JRE. \%IE rises with expanding the concentrations of the extract. Supplement of the extract moves the corrosion potentials somewhat the negative way without an obvious change in $\beta \mathrm{a}$ and $\beta \mathrm{c}$ values.

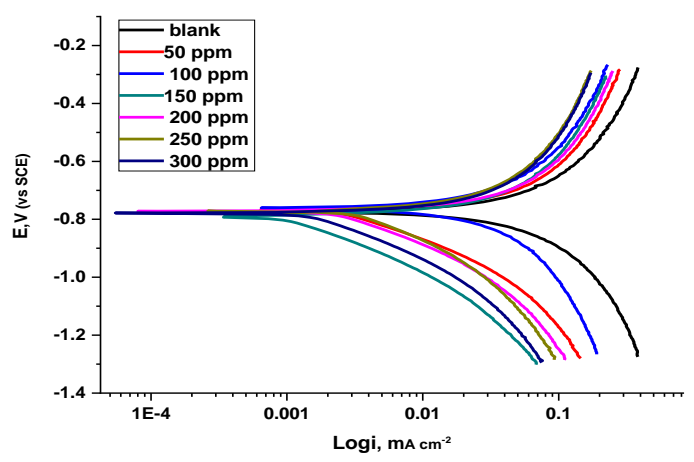

Fig. 2. Polarization bends for the dissolution of $\mathrm{Al}$ in $2 \mathrm{M} \mathrm{HCl}$ in the absence and presence of (JRE) at $25^{\circ} \mathrm{C}$.

Figure 2 shows that the icorr values decline by the addition of the extract which lessening the $\mathrm{Al}$ dissolution. The expansion of the extract has an inhibitive impact in both the anodic and cathodic directions of the polarization bends, and the expansion of the extract moved the $\mathrm{E}_{\text {corr }}$ value towards the negative heading compared with the blank Al. Hence, addition of JRE diminishes the Al corrosion just as delays the hydrogen formation reaction. Equal cathodic Tafel curves in Figure 2 demonstrated that the hydrogen evolution is actuation controlled and that the decrease instrument isn't influenced by the nearness of JRE [29] based on the experimental information, JRE acts as inhibitor of mixed-type.

\subsection{Electrochemical impedance spectroscopy method (EIS).}

The dissolution attitude of $\mathrm{Al}$ in $2 \mathrm{M} \mathrm{HCl}$ medium with and without various concentrations of (JRE) was researched by EIS technique at $25 \pm 1 \mathrm{C} 0$ after $30 \mathrm{~min}$ of submersion. Figure 3 illustrates the nyquist plot for aluminum in $2 \mathrm{M} \mathrm{HCl}$ medium without and with several amounts of JRE. The way that impedance charts have an around semi-round appearance demonstrates that the dissolution of $\mathrm{Al}$ in $2 \mathrm{M} \mathrm{HCl}$ is constrained by a charge transfer impedance process. A little bending was seen in certain outlines, and this contortion has been credited to recurrence scattering [30] because of surface unpleasantness, contaminations, separations, grain limits, adsorption of inhibitors and arrangement of permeable layers.

The capacitive circle diameter rises with the expansion of the amount of JRE and is demonstrative of the level of inhibitive influence of the consumption procedure. The inductive circle is by and large ascribed to the adsorption of species coming about because of the Al dissolution and the $\mathrm{H} 2$ adsorption [31]. 
Table 2. Outcomes from polarization of $\mathrm{Al}$ in $2 \mathrm{M} \mathrm{HCl}$ including several concentrations of (JRE) at $25^{\circ} \mathrm{C}$.

\begin{tabular}{|c|c|c|c|c|c|c|c|}
\hline $\begin{array}{l}\text { Conc., } \\
\text { ppm }\end{array}$ & $\begin{array}{l}-\mathbf{E}_{\text {corr }}, \mathbf{m V} \\
\text { (vs SCE) }\end{array}$ & 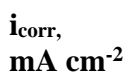 & $\begin{array}{l}\beta_{\mathrm{a}} \\
\mathrm{V} \operatorname{dec}^{-1}\end{array}$ & $\begin{array}{l}\beta_{\mathrm{c}} \\
\mathrm{V} \operatorname{dec}^{-1}\end{array}$ & $\begin{array}{l}\text { C.R, } \\
\text { mpy }\end{array}$ & $\boldsymbol{\Theta}$ & $\%$ IE \\
\hline $\mathbf{0}$ & 774.0 & 847.0 & 7.648 & 5.23 & 363.9 & ---- & $\begin{array}{ll}--- \\
\end{array}$ \\
\hline 50 & 762.3 & 187.2 & 1.45 & 2.48 & 160.5 & 0.779 & 77.9 \\
\hline 100 & 831.2 & 171.1 & 1.73 & 2.35 & 147.0 & 0.798 & 79.8 \\
\hline 150 & 826.6 & 126.4 & 1.89 & 1.07 & 108.4 & 0.851 & 85.1 \\
\hline 200 & 885.1 & 85.9 & 1.56 & 1.36 & 73.7 & 0.899 & 89.9 \\
\hline 250 & 784.3 & 32.9 & 1.29 & 1.34 & 28.2 & 0.961 & 96.1 \\
\hline 300 & 779.0 & 10.9 & 1.11 & 1.42 & 9.3 & 0.987 & 98.7 \\
\hline
\end{tabular}

The utilized circuit model that appeared in Figure 4 was applied to break down the acquired impedance information. The model comprises of the resistance of corrosive solution $\left(\mathrm{R}_{\mathrm{s}}\right)$, the charge transfer resistance $\left(\mathrm{R}_{\mathrm{ct}}\right)$, the inductance $(\mathrm{L})$, the inductive resistance $\left(\mathrm{R}_{\mathrm{L}}\right)$, and the double layer capacitance $\left(\mathrm{C}_{\mathrm{dl}}\right)$. A great fit with the applied model was acquired with our obtained information [32]. At the point when an inductive circle is available, the polarization resistance $\left(R_{P}\right)$ can be determined from the accompanying eq. (5):

$$
\mathrm{R}_{\mathrm{P}}=\left(\mathrm{R}_{\mathrm{ct}} \times \mathrm{R}_{\mathrm{L}}\right) /\left(\mathrm{R}_{\mathrm{ct}}+\mathrm{R}_{\mathrm{L}}\right)
$$

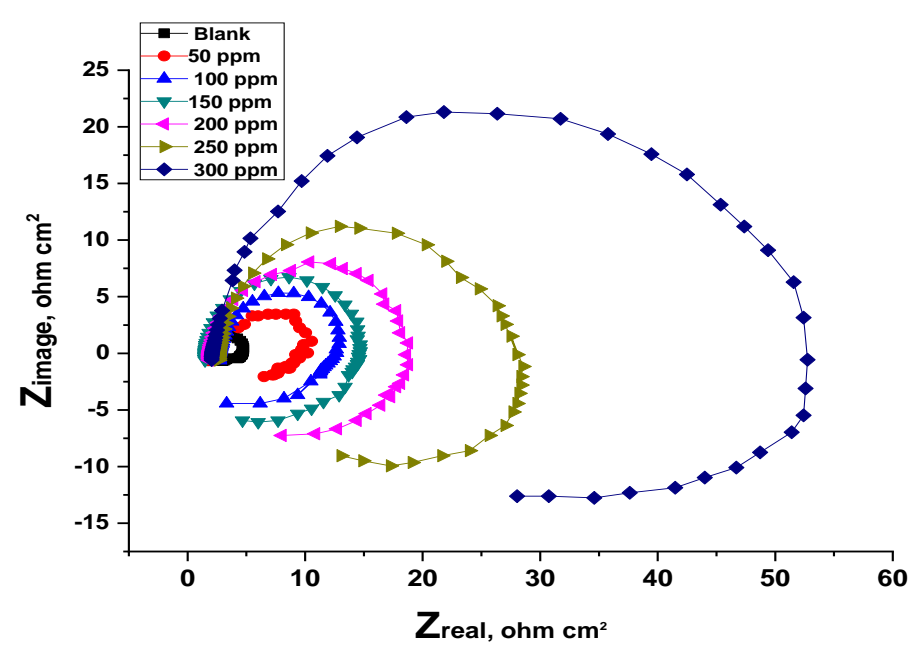

Figure 3. Nyquist diagrams of $\mathrm{Al}$ in $2 \mathrm{M} \mathrm{HCl}$ without and with several concentrations of Juglans Regia extract at $25^{\circ} \mathrm{C}$.

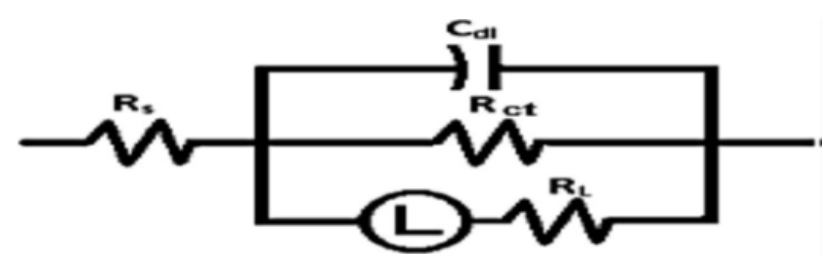

Figure 4. Equivalent circuit applied to fit the impedance outcomes.

EIS information from Table 3 illustrates that the $R_{P}$ values rise and the $C_{d l}$ values decline with the expansion of JRE amounts. This is because of the continuous substitution of $\mathrm{H}_{2} \mathrm{O}$ particles by the adsorption of JRE molecules on the $\mathrm{Al}$ outer surface, and diminishing the degree of the consumption reaction. The large RP values are correlated to a small corrosion framework $[33,34]$. The decline in the Cdl is related to the decrease of the local dielectric constant or potentially from the expansion of intensity of the electric double layer [35], proposing that JRE particles inhibit corrosion by adsorption at the metal outer surface. 
Table 3. Electrochemical parameters acquired from $\mathrm{EIS}$ for $\mathrm{Al}$ in $2 \mathrm{M} \mathrm{HCl}$ medium in the non-attendance and existence of several amounts of Juglans Regia extract at $25^{\circ} \mathrm{C}$.

\begin{tabular}{|c|c|c|c|c|}
\hline Conc., ppm & $R_{p}, \Omega \mathbf{c m}^{2}$ & $\mathrm{C}_{\mathrm{dl}}, \mu \mathrm{Fcm}^{-2}$ & $\Theta$ & $\%$ IE \\
\hline Blank & 1.44 & 75.67 & ---- & ---- \\
\hline 50 & 4.21 & 39.94 & 0.658 & 65.8 \\
\hline 100 & 5.75 & 32.29 & 0.750 & 75.0 \\
\hline 150 & 7.22 & 28.80 & 0.801 & 80.1 \\
\hline 200 & 7.81 & 26.78 & 0.816 & 81.6 \\
\hline 250 & 8.47 & 23.34 & 0.830 & 83.0 \\
\hline 300 & 9.91 & 19.10 & 0.855 & 85.5 \\
\hline
\end{tabular}

\subsection{Electrochemical frequency modulation (EFM),}

EFM is a non-destructive corrosion estimation framework which able to explicitly and quickly decide the dissolution current characteristics without earlier information on Tafel slopes, and with only a bit of polarizing signal. The major purposes of EFM system make it an ideal contender for online dissolution monitoring [36]. The perfect quality of the EFM is the parameter of the causality factors that fill in as an interior test on the validity of the calculated estimations. The causality parts CF-2 and CF-3 are determined from the frequency range of the present reactions. Figure 5 exhibits the EFM Intermodulation spectrum (frequency versus current) of $\mathrm{Al}$ in $2 \mathrm{M} \mathrm{HCl}$ medium including several amounts of (JRE) [37]. The bigger tops were applied to compute the dissolution current (icorr), the Tafel slopes ( $\beta \mathrm{c}$ and $\beta \mathrm{a}$ ) and the causality factors (CF-2 and CF-3). All estimations were put in Table 4. The outcomes that appeared in Table 4 clearly exhibit that, the expansion of (JRE) at an offered concentration to the acidic arrangement diminishes the dissolution current density, demonstrating that this extract restrains the corrosion of $\mathrm{Al}$ in $2 \mathrm{M} \mathrm{HCl}$. The causality factors acquired under several empirical cases are roughly equal to the theoretical levels ( 2 and 3 ) showing that the deliberate information is checked and of perfect form. The inhibition efficiencies \% IE EFM increase by expanding the inhibitor concentrations and was determined as from Eq. (1).
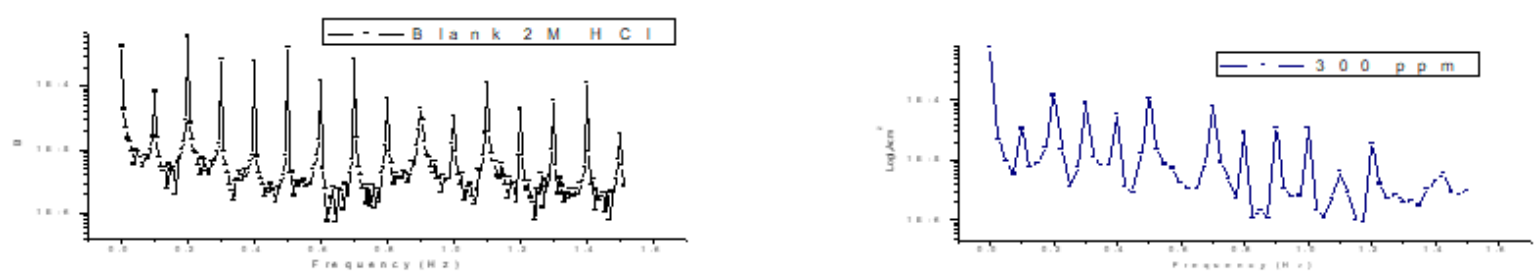

Figure 5. EFM spectra for $\mathrm{Al}$ in $2 \mathrm{M} \mathrm{HCl}$ without and with existence of $300 \mathrm{ppm}$ of $\mathrm{JRE}$ at $25^{\circ} \mathrm{C}$.

Table 4. Electrochemical outcomes acquired from EFM for $\mathrm{Al}$ in the absence and existence of several amounts

\begin{tabular}{c|c|c|c|c|c|c|c|c}
\multicolumn{8}{c}{ Juglans Regia extract in $2 \mathrm{M} \mathrm{HCl}$ at $25^{\circ} \mathrm{C}}$. \\
$\begin{array}{c}\text { Conc., } \\
\mathrm{ppm}\end{array}$ & $\begin{array}{c}\mathrm{i}_{\text {corr, }} \\
\mu \mathrm{Acm}^{-2}\end{array}$ & $\begin{array}{c}\beta_{\mathrm{a},} \\
\mathrm{mVdec}^{-1}\end{array}$ & $\begin{array}{c}\beta_{\mathrm{c}}, \\
\mathrm{mVdec}^{-1}\end{array}$ & $\mathrm{CF}-2$ & $\mathrm{CF}-3$ & $\begin{array}{c}\text { C.R, } \\
\mathrm{mpy}\end{array}$ & $\theta$ & $\%$ IE \\
\hline Blank & 831.4 & 67.4 & 39.1 & 1.85 & 1.68 & 357.0 & ---- & ---- \\
\hline 50 & 225.9 & 22.7 & 125.4 & 2.85 & 2.87 & 109.1 & 0.728 & 72.8 \\
\hline 100 & 139.9 & 20.5 & 323.2 & 2.57 & 2.65 & 60.1 & 0.832 & 83.2 \\
\hline 150 & 108.8 & 18.2 & 273.2 & 2.69 & 3.02 & 46.7 & 0.869 & 86.9 \\
\hline 200 & 95.8 & 24.4 & 223.9 & 2.83 & 2.57 & 41.1 & 0.885 & 88.5 \\
\hline 250 & 70.9 & 18.5 & 113.6 & 2.85 & 3.11 & 30.5 & 0.915 & 91.5 \\
\hline 300 & 51.2 & 23.9 & 195.3 & 2.61 & 2.78 & 20.0 & 0.938 & 93.8
\end{tabular}




\subsection{Mass loss tests.}

The consumption rates of $\mathrm{Al}$ were researched. Fig. 6 performs the mass loss against time without and with of changed amounts of JRE at $25^{\circ}$. Clearly, the consistency and nonlinearity of the plot without inhibitor recommend that the $\mathrm{Al}$ consumption in $2 \mathrm{M} \mathrm{HCl}$ is a heterogeneous procedure including several stages. Comparable noticing has been shown for $\mathrm{Al}$ dissolution in other corrosive medium [38]. The surface coverage $(\theta)$ and $\%$ IE that demonstrate the mass of $\mathrm{Al}$ outer surface secured by JRE molecules were appeared in Tables 5. \%IE rises with expanding JRE concentrations demonstrated that more JRE particles are adsorbed. This way gives more extensive surface coverage. The ideal concentration desired to attain \%IE of $97.5 \%$ was seen as $300 \mathrm{ppm}$ for the inhibitor.

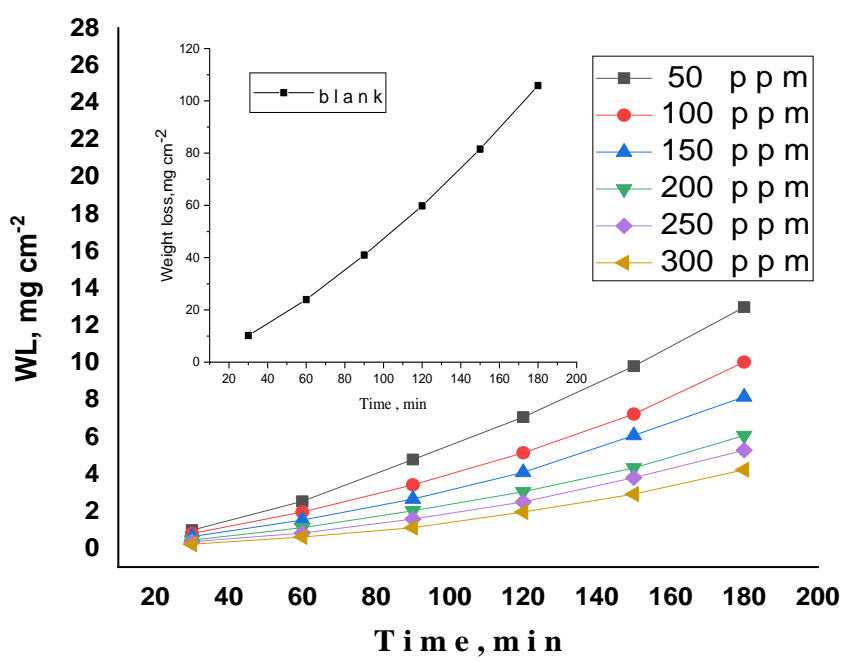

Figure 6. Mass loss-time plots for the dissolution of $\mathrm{Al}$ in $2 \mathrm{M} \mathrm{HCl}$ in the absence and existence of several concentrations of JRE at $25^{\circ} \mathrm{C}$.

Table 5. Consumption rate and inhibitive efficiency data acquired from mass loss calculations for $\mathrm{Al}$ in $2 \mathrm{M}$ HCL solutions in the absence and existence different amounts of JRE at $25^{\circ} \mathrm{C}$.

\begin{tabular}{l|l|l|l} 
Conc., ppm & C.R., $\mathbf{~ m g . c m}^{-2} \cdot \mathbf{m i n}^{-\mathbf{1}}$ & $\boldsymbol{\theta}$ & $\mathbf{\%} \mathbf{I E}$ \\
\hline blank & 0.455 & $\ldots \ldots \ldots$ & $\ldots \ldots \ldots \ldots$. \\
\hline $\mathbf{5 0}$ & 0.053 & 0.883 & 88.3 \\
\hline $\mathbf{1 0 0}$ & 0.038 & 0.916 & 91.6 \\
\hline $\mathbf{1 5 0}$ & 0.030 & 0.935 & 93.5 \\
\hline $\mathbf{2 0 0}$ & 0.022 & 0.951 & 95.1 \\
\hline $\mathbf{2 5 0}$ & 0.018 & 0.961 & 96.1 \\
\hline $\mathbf{3 0 0}$ & 0.012 & 0.973 & 97.3
\end{tabular}

\subsubsection{Adsorption isotherms.}

Dissolution inhibitors are appeared to secure $\mathrm{Al}$ consumption in corrosive mediums by adsorbing these extracts on $\mathrm{Al}$ surface where the adsorption of the natural molecules exists because of the binding energy among the $\mathrm{H}_{2} \mathrm{O}$ particles and the outer surface is lower than that among particles and metal surface [39]. It is viewed as an exchange adsorption procedure between $\mathrm{H}_{2} \mathrm{O}$ particles and the natural products present in the aqueous state (org aq) [40].

$$
\mathrm{XH}_{2} \mathrm{O} \text { ads }+\mathrm{Org}_{\text {sol }} \leftrightarrow \mathrm{Org} \text { ads }+\mathrm{xH}_{2} \mathrm{O}
$$

Where $\mathrm{x}$ is the volume ratio which is the quantity of $\mathrm{H}_{2} \mathrm{O}$ particles supplanted by single organic particle. The particles may be physisorbed or chemisorbed on the metal outer surface, where 
the physisorbed molecules impede metal consumption by lowering the cathodic response while chemisorbed particles hinder the anodic response by decreasing the potential reaction of the corroding metal at the adsorption locations [41]. It was discovered that the perfect reasonable adsorption isotherm is Langmuir equation that was characterized as following [42]:

$$
\left(\frac{\theta}{1-\theta}\right)=\text { Kads } C
$$

Where $\mathrm{C}$ is the concentration (ppm) of JRE, $\theta$ is the level of surface coverage; $\mathrm{K}_{\text {ads }}$ is the adsorption equilibrium consistent. A graph of $\theta /(1-\theta)$ against $C$ affords straight lines and the slope is equivalent to $\mathrm{K}_{\mathrm{ads}}$ as appeared in Fig. 7. All thermodynamic parameters of adsorption were determined .The notable parameters are the free energy of adsorption $\left(\Delta \mathrm{G}_{\mathrm{ads}}^{\circ}\right)$, the enthalpy $\left(\Delta \mathrm{H}^{\circ}\right.$ ads $)$ and the entropy $\left(\Delta \mathrm{S}^{\circ}\right.$ ads). These amounts can be determined by different scientific techniques relying upon the estimations of $K_{\text {ads }}$ at various temperatures (Fig.8) [43]. The change in free energy can be determined from eq. (8):

$$
\mathrm{K}_{\mathrm{ads}}=(1 / 55.5) \exp \left(-\Delta \mathrm{G}^{\circ} \text { ads } / \mathrm{RT}\right)
$$

Where 55.5 is the amount of $\mathrm{H}_{2} \mathrm{O}$ in $\mathrm{mol} \mathrm{l}^{-1}$, $\mathrm{T}$ is the temperature and $\mathrm{R}$ is the universal gas constant. $\left(\Delta \mathrm{H}^{\circ}\right.$ ads $),\left(\Delta \mathrm{S}^{\circ}\right.$ ads $)$ can be determined from eq. $(9 \& 10)$ :

$$
\begin{aligned}
& \log \mathrm{K}_{\text {ads }}=\left(-\Delta \mathrm{H}^{\circ} \text { ads } / 2.303 \mathrm{RT}\right)+\text { constant } \\
& \Delta \mathrm{G}^{\circ}{ }_{\text {ads }}=\Delta \mathrm{H}^{\circ} \text { ads }-\mathrm{T} \Delta \mathrm{S}^{\circ}{ }_{\text {ads }}
\end{aligned}
$$

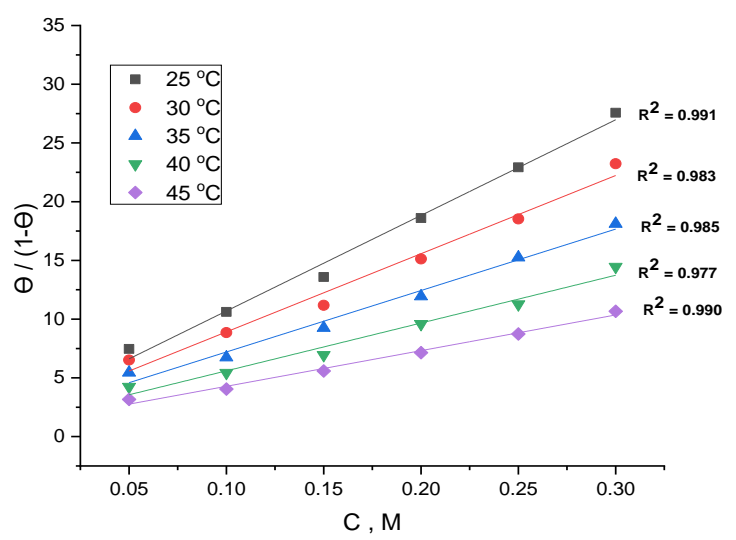

Figure 7. Graph fitting of dissolution outcomes for $\mathrm{Al}$ in $2 \mathrm{M} \mathrm{HCl}$ in existence of several concentrations of JRE to Langmuir isotherm at various temperatures.

Table 6 demonstrates the calculated thermodynamic parameters and illustrated that the indication of $\Delta \mathrm{G}^{\circ}$ ads was negative that indicates that JRE is adsorbed in spontaneous procedure. It is notable that estimations of $\Delta \mathrm{G}^{\circ}$ ads of $40 \mathrm{~kJ} \mathrm{~mol}^{-1}$ or larger include charge participation or move from the inhibitor particles to metal surface by coordination bond (chemisorption); but the values of $20 \mathrm{~kJ} \mathrm{~mol}^{-1}$ or smaller implies that the electrostatic interference among metal outer surface and charged particles in the majority of the corrosive medium demonstrate physisorption $[44,45]$. The determined values of $\Delta \mathrm{G}^{\circ}$ ads are $-20 \mathrm{~kJ} \mathrm{~mol}^{-1}$ and lower which predictable with the electrostatic interaction between the charged particles and the charged metal (physical adsorption). $\Delta \mathrm{G}_{\text {ads }}^{\circ}$ values rises (be more positive) with an expansion in temperature that demonstrates that the adsorption procedure is an exothermic procedure. The 
negative indication of $\Delta \mathrm{H}^{\circ}$ ads demonstrates that the adsorption procedure of the inhibitor particles is an exothermic procedure. By and large, an exothermic procedure recommends either physisorption or chemisorption while endothermic procedure is ascribed to chemisorption [46]. In general, enthalpy amounts around $41.9 \mathrm{~kJ} \mathrm{~mol}^{-1}$ are identified with physisorption but these up to $100 \mathrm{~kJ} \mathrm{~mol}^{-1}$ or larger are ascribed to chemisorption. The determined $\Delta \mathrm{H}^{\circ}$ ads estimations are negative demonstrating that (JRE) might be physisorbed. The $\Delta \mathrm{S}^{\circ}$ ads estimations are negative which is related to exothermic adsorption process and illustrated that the inhibitor particles, moving freely in the electrolyte were adsorbed in a systematic mode onto the Al surface.

Table 6. Thermodynamic calculations for the adsorption of JRE on $\mathrm{Al}$ surface in $2 \mathrm{M} \mathrm{HCl}$ at various temperatures.

\begin{tabular}{|c|c|c|c|c|}
\hline \multicolumn{5}{|c|}{ 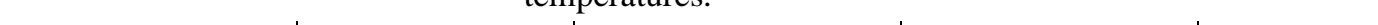 } \\
\hline $\begin{array}{c}\text { Temperature , } \\
\mathrm{C}^{\mathbf{0}} \\
\end{array}$ & $\begin{array}{c}\mathbf{K}_{\text {ads }}, \\
\mathbf{M}^{-1}\end{array}$ & $\begin{array}{l}\mathbf{G}_{\text {ads }}^{0},-\Delta \\
\text { kJ mole } \\
\end{array}$ & $\begin{array}{l}-\Delta \mathbf{H}^{\circ} \text { ads, } \\
\mathbf{k J ~ m o l}^{-1}\end{array}$ & $\begin{array}{c}-\Delta \mathbf{S}_{\text {ads }}^{0} \\
\mathbf{J ~ m o l}^{-1} \mathbf{K}^{-1} \\
\end{array}$ \\
\hline 25 & 81.4 & 20.9 & \multirow{5}{*}{38.8} & 60.1 \\
\hline 30 & 66.6 & 20.7 & & 59.7 \\
\hline 35 & 52.3 & 20.4 & & 59.7 \\
\hline 40 & 40.7 & 20.1 & & 59.7 \\
\hline 45 & 30.4 & 19.6 & & 60.4 \\
\hline
\end{tabular}

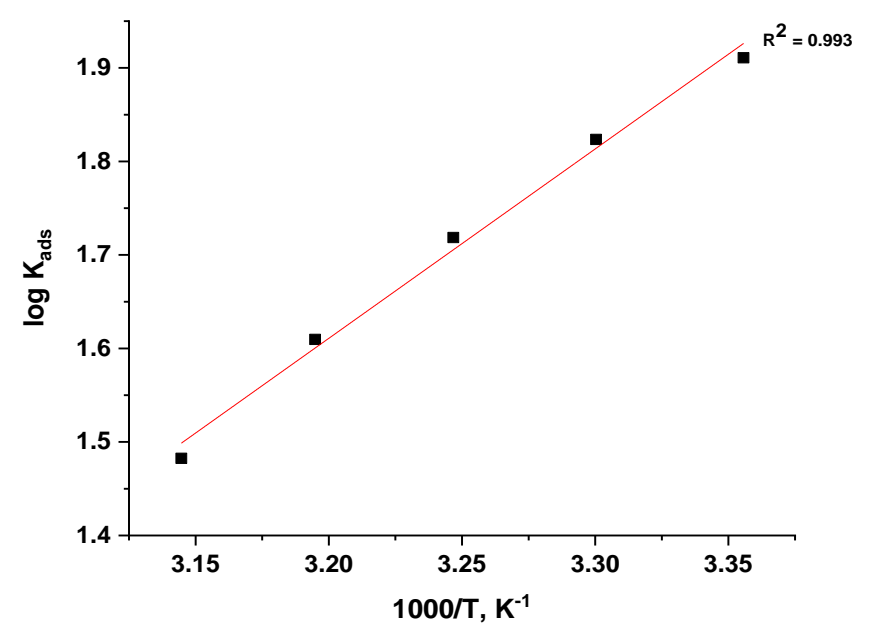

Figure 8. $\left(\log \mathrm{K}_{\mathrm{ads}}\right)$ against $(1 / \mathrm{T})$ for the dissolution of $\mathrm{Al}$ in $2 \mathrm{M} \mathrm{HCl}$ in the existence of Juglans Regia extract.

3.4.2. Thermodynamic consumption parameters.

The activation factors for the dissolution procedure were illustrated according to Arrhenius eq. (11):

$$
\text { C.R }=\mathrm{A} \exp \left(\mathrm{E}_{\mathrm{a}}^{*} / \mathrm{RT}\right)
$$

Where C.R. represents the consumption ratio, $R$ is the universal gas consistent, $E^{*}$ a represents the evident activation dissolution energy, $\mathrm{T}$ represents the temperature and $\mathrm{A}$ refers to the Arrhenius constant. Estimations of $\mathrm{E}^{*}{ }_{\mathrm{a}}$ of dissolution for $\mathrm{Al}$ in the existence of various amounts of (JRE) were resolved from the relation of $\log$ (C.R.) against 1/T graphs as appeared in Fig. 9. The elective definition of transition state relation has appeared in eq. (12):

$$
\text { C.R. }=(\mathrm{RT} / \mathrm{Nh}) \exp \left(\Delta \mathrm{S}^{*} / \mathrm{R}\right) \exp \left(-\Delta \mathrm{H}^{*} / \mathrm{RT}\right)
$$

Where $\mathrm{N}$ is related to Avogadro's factor, $\mathrm{h}$ is referred to Planck's parameter, $\Delta \mathrm{S}^{*}$ represents the activated entropy and $\Delta H^{*}$ is related to the activated enthalpy. A diagram of $(\log$ C.R./T) versus $(1 / \mathrm{T})$ illustrates straight lines as indicated in Fig. 10 with slopes equivalent to $\left(\Delta H^{*} / 2.303 R\right)$ 
and intercepts $\log \left(\mathrm{R} / \mathrm{Nh}+\Delta \mathrm{S}^{*} / 2.303 \mathrm{R}\right)$. All calculations are listed in Table 7 . The expansion in $\mathrm{E}^{*}$ a estimations demonstrated that JRE is physisorbed on the Al outer surface [47]. The positive indications of $\Delta \mathrm{H}^{*}$ values illustrated the endothermic idea of the Al dissolution procedure. The negative indications of $\Delta S^{*}$ demonstrated that in the rate computing step, the association of unstable coordinated particles is larger than the dissociation [48, 49].

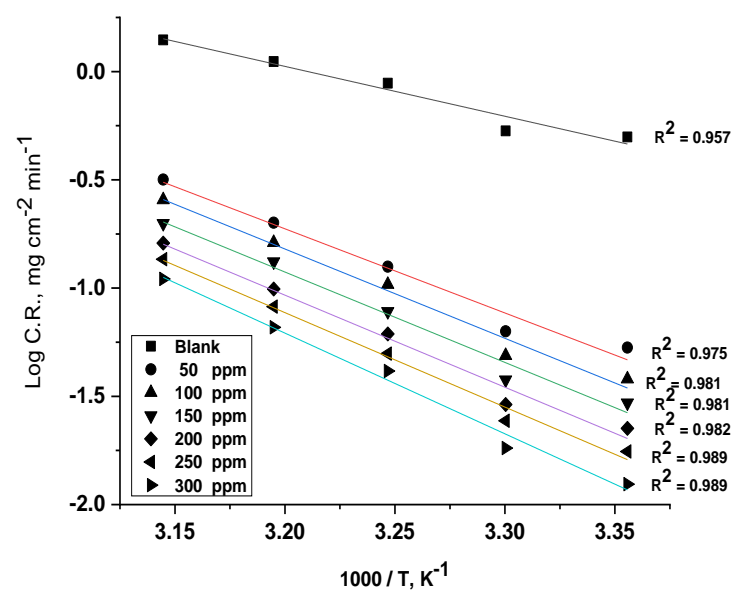

Figure 9. Arrhenius graphs for $\mathrm{Al}$ dissolution rates $\left(\mathrm{k}_{\text {corr. }}\right)$ after 90 minute of dipping in $2 \mathrm{M} \mathrm{HCl}$ in the blank and existence of several amounts of JRE.

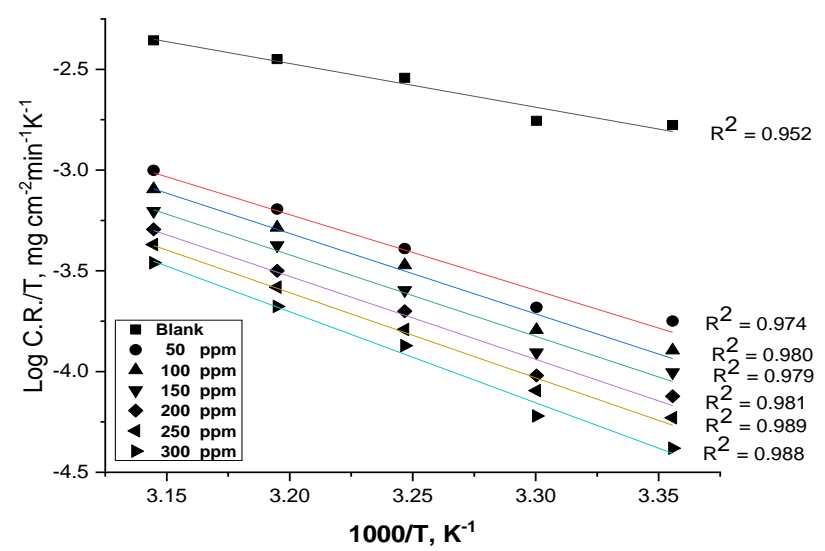

Figure 10. Transition-state for $\mathrm{Al}$ dissolution rates $\left(\mathrm{k}_{\text {corr }}\right)$ in $2 \mathrm{M} \mathrm{HCl}$ in the blank and existence of several amounts of JRE.

Table 7. Activation calculations for $\mathrm{Al}$ dissolution in $2 \mathrm{M} \mathrm{HCl}$ in the blank and existence of several amounts of JRE.

\begin{tabular}{|c|c|c|c|}
\hline \multirow[t]{2}{*}{ Conc., ppm } & \multicolumn{3}{|c|}{ Activation parameters } \\
\hline & $\mathrm{E}_{\mathrm{a}}^{*}, \mathrm{~kJ} \mathrm{~mol}^{-1}$ & $\Delta \mathbf{H}^{*}, \mathbf{k J} \mathbf{~ m o l}^{-1}$ & 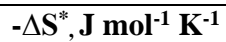 \\
\hline Blank & 44.1 & 41.5 & 111.9 \\
\hline 50 & 74.4 & 71.8 & 29.3 \\
\hline 100 & 78.9 & 76.4 & 16.4 \\
\hline 150 & 79.9 & 77.3 & 15.5 \\
\hline 200 & 81.4 & 78.8 & 12.7 \\
\hline 250 & 83.5 & 80.9 & 7.6 \\
\hline 300 & 89.1 & 86.5 & 8.3 \\
\hline
\end{tabular}

3.4.3. Influence of Temperature.

The influence of temperature on the dissolution rate of $\mathrm{Al}$ in $2 \mathrm{M} \mathrm{HCl}$ and in the nearness of various inhibitor amounts was considered in the temperature from (25-45) $\mathrm{C}^{\mathrm{o}}$ utilizing mass 
loss method. As the temperature rises, the rate of consumption rises and \%IE of the added substances decrease as appeared in Table 8.

Table 8. Variation of inhibition efficiencies (\% IE) and surface coverage ( $\theta)$ for several amounts of JRE at

\begin{tabular}{|c|c|c|c|}
\hline Conc., ppm & Temp., $\mathrm{C}^{\mathrm{o}}$ & Weight loss, $\mathrm{mg} / \mathrm{cm}^{2}$ & $\boldsymbol{\theta}$ \\
\hline \multirow[t]{5}{*}{50} & 25 & 4.783 & 0.883 \\
\hline & 30 & 5.675 & 0.872 \\
\hline & 35 & 11.308 & 0.850 \\
\hline & 40 & 18.033 & 0.813 \\
\hline & 45 & 28.508 & 0.767 \\
\hline \multirow[t]{5}{*}{100} & 25 & 3.425 & 0.916 \\
\hline & 30 & 4.392 & 0.901 \\
\hline & 35 & 9.367 & 0.876 \\
\hline & 40 & 14.583 & 0.848 \\
\hline & 45 & 23.042 & 0.812 \\
\hline \multirow[t]{5}{*}{150} & 25 & 2.658 & 0.935 \\
\hline & 30 & 3.392 & 0.923 \\
\hline & 35 & 7.025 & 0.907 \\
\hline & 40 & 11.917 & 0.876 \\
\hline & 45 & 17.925 & 0.854 \\
\hline \multirow[t]{5}{*}{200} & 25 & 2.025 & 0.951 \\
\hline & 30 & 2.608 & 0.941 \\
\hline & 35 & 5.525 & 0.927 \\
\hline & 40 & 8.917 & 0.907 \\
\hline & 45 & 14.533 & 0.881 \\
\hline \multirow[t]{5}{*}{250} & 25 & 1.583 & 0.961 \\
\hline & 30 & 2.192 & 0.950 \\
\hline & 35 & 4.483 & 0.941 \\
\hline & 40 & 7.383 & 0.923 \\
\hline & 45 & 12.217 & 0.900 \\
\hline \multirow[t]{5}{*}{300} & 25 & 1.117 & 0.973 \\
\hline & 30 & 1.642 & 0.963 \\
\hline & 35 & 3.725 & 0.951 \\
\hline & 40 & 5.933 & 0.938 \\
\hline & 45 & 9.925 & 0.919 \\
\hline
\end{tabular}

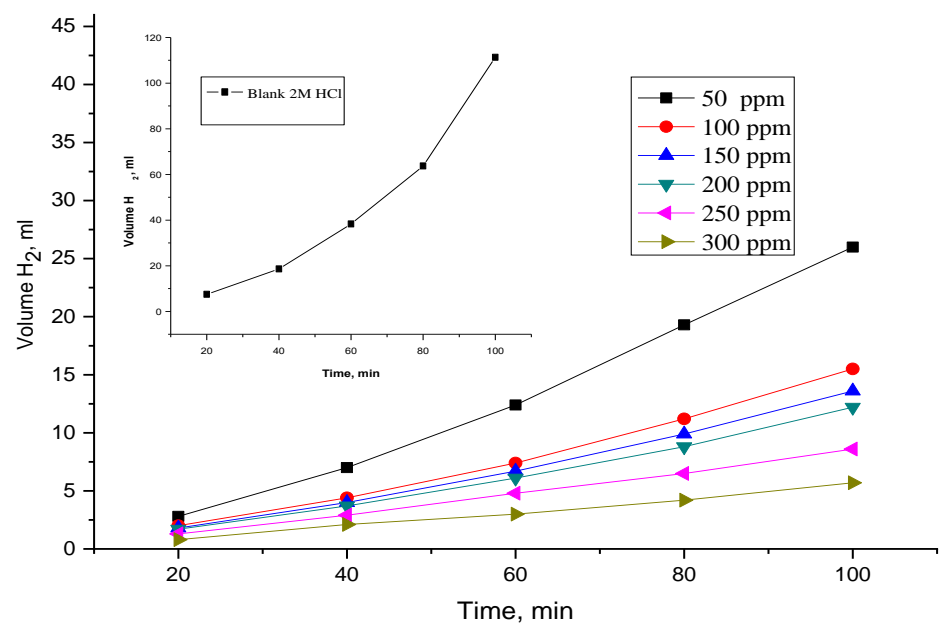

Figure 11. Amounts of emitted $\mathrm{H}_{2}$ gas vs. time for consumption of $\mathrm{Al}$ in $2 \mathrm{M} \mathrm{HCl}$ at several concentrations of Juglans Regia extract at $25^{\circ} \mathrm{C}$.

\subsection{Hydrogen evolution method (HE).}

The created $\mathrm{H}_{2}$ gas amount obtained from the consumption procedure can be determined. Outcomes got by this technique in Fig. 11 are matching with several techniques like electrochemical measurements and mass loss technique. The emitted $\mathrm{H}_{2}$ is reliant on the reaction period according to eq. (13): 


$$
\mathrm{V}_{\mathrm{ml}}=\mathrm{k}_{\text {corr }} . \mathrm{t}
$$

$\mathrm{V}$ is the quantity of the $\mathrm{H}_{2}$ emitted in $\mathrm{ml}, \mathrm{t}$ represents the time and $\mathrm{k}_{\text {corr }}$ is dissolution rate at $25 \mathrm{C}^{\mathrm{o}}[50]$.

The emitted $\mathrm{H}_{2}$ volume was computed every 20 min, \% IE and $\mathrm{K}_{\text {corr }}$ were measured by eq. (14):

$$
\% \mathrm{IE}=\left(1-\mathrm{K} / \mathrm{K}_{\mathrm{o}}\right) \times 100
$$

$\mathrm{K}$ and $\mathrm{K}_{\mathrm{o}}$ are the $\mathrm{k}_{\text {corr }}$ in presence and non-existence of various doses of JRE, by graphing Vml versus $t$ and $K_{\text {corr }}$ is the slope.

Table 9 illustrates the dissolution rate reduced and the rising of \%IE with rise of (JRE) concentration.

Table 9. IE\% and ( $\mathrm{k}_{\text {corr }}$ from $\mathrm{HE}$ for the $\mathrm{Al}$ consumption in the tested mediums of several amounts of Juglans Regia extract at $25^{\circ} \mathrm{C}$.

\begin{tabular}{l|l|l} 
Conc., $\mathbf{p p m}$ & $\mathbf{k}_{\mathbf{c o r r} \times 10^{-3}}, \mathbf{m l} / \mathbf{m i n}$ & $\mathbf{\%} \mathbf{I E}$ \\
\hline Blank & 1200 & ---- \\
\hline 50 & 293.5 & 75.5 \\
\hline 100 & 169 & 85.9 \\
\hline 150 & 147.5 & 87.7 \\
\hline 200 & 130.5 & 89.1 \\
\hline 250 & 91 & 92.4 \\
\hline 300 & 59.5 & 95.0
\end{tabular}

\subsection{Atomic force microscope (AFM) examination.}

AFM gives pictures for outer surface topography with perfect precision, able to determine the roughness of the examined surface. The 3D AFM morphologies for pure Al outer surface and $\mathrm{Al}$ in $2 \mathrm{M} \mathrm{HCl}$ in the absence and existence of (JRE) have appeared as Fig. 12.

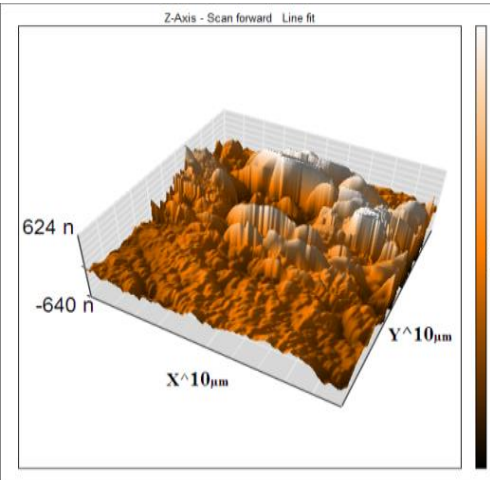

A

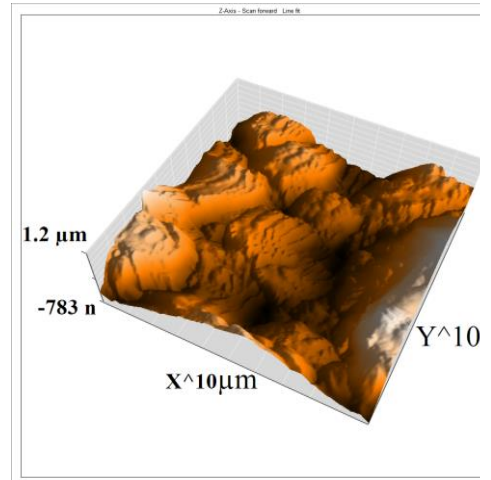

B

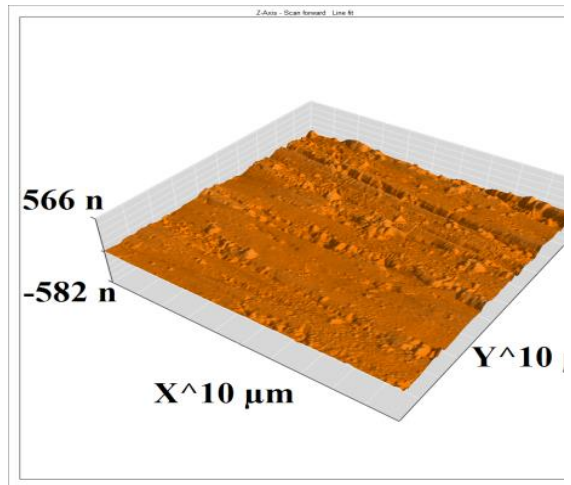

C

Figure 12. 3D AFM of the surface of: $\mathrm{A}$ ) pure $\mathrm{Al}$ outer surface; $\mathrm{B}$ ) $\mathrm{Al}$ dipped in $2 \mathrm{M} \mathrm{HCl}$; $\mathrm{C}$ ) $\mathrm{Al}$ dipped in $2 \mathrm{M}$ $\mathrm{HCl}$ having $300 \mathrm{ppm}$ of JRE.

The photograph of the $\mathrm{Al}$ outer surface in $2 \mathrm{M} \mathrm{HCl}$ has a larger roughness $(381.1 \mathrm{~nm})$ than the cleaned aluminum sample $(15.6 \mathrm{~nm})$, that demonstrates that the Al sample is industriously corroded because of the corrosive aggression. The obtained roughness of inhibited $\mathrm{Al}$ is diminished and shifted to $(117.4 \mathrm{~nm})$. This is due to the consistency of a compacted adsorbed layer on the outer surface thereby impeding the dissolution of $\mathrm{Al}$ [51]. 


\subsection{FTIR analysis of the extract and corrosion product.}

FTIR spectroscopy shows good features, for example, high sign to commotion proportion, high affectability and selectivity, precision, mechanical straightforwardness, short examination time and modest quantity of test desired for the investigation [52]. From Fig. 13 the FTIR spectrum of the unadulterated concentrate has appeared. The expansive band acquired at $3329 \mathrm{~cm}^{-1}$ can be doled out to $(\mathrm{OH})$. The band at $\left(2973,2928\right.$ and 2882) $\mathrm{cm}^{-1}$ relates to $\left(\mathrm{CH}_{3}\right)$ and $(\mathrm{C}-\mathrm{H})$ extending, the top at $1669 \mathrm{~cm}^{-1}$ compares to $(\mathrm{C}=\mathrm{C})$, the band at $1046 \mathrm{~cm}^{-1}$ can be allocated to $(\mathrm{C}-\mathrm{O})$ stretch, the one at $1380 \mathrm{~cm}^{-1}$ relates to $(\mathrm{C}-\mathrm{H})$ holding and the peak at 880 $\mathrm{cm}^{-1}$ is expected to $(=\mathrm{CH} 2,=\mathrm{C}-\mathrm{H})$.

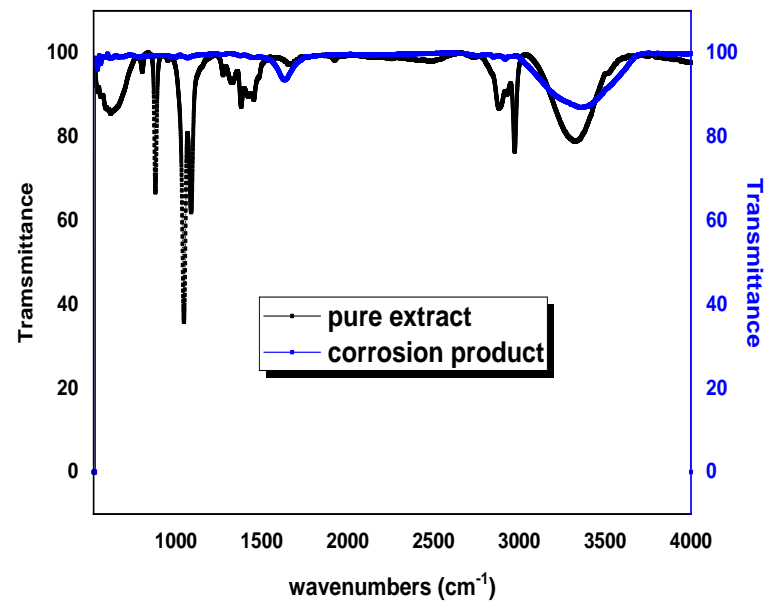

Figure 13. IR spectra of pure extract and corrosion products of Aluminum after the weight loss test in existence of $300 \mathrm{ppm}$ of JRE at $25^{\circ} \mathrm{C}$.

There are shifts and moves in the frequencies. The stretch of $(\mathrm{O}-\mathrm{H})$ at $3329 \mathrm{~cm}^{-1}$ was moved to $3362 \mathrm{~cm}^{-1}$, the $\mathrm{C}=\mathrm{C}$ bond at $1669 \mathrm{~cm}^{-1}$ was moved to $1633 \mathrm{~cm}^{-1}$, the $(\mathrm{C}-\mathrm{H})$ stretch at $2973 \mathrm{~cm}^{-1}$ was moved to $2918 \mathrm{~cm}^{-1}$, (C-O) stretch at $1046 \mathrm{~cm}^{-1}$ was moved to $1069 \mathrm{~cm}^{-1}$. These results indicated the interference between the inhibitor and $\mathrm{Al}$ surface. The shifts in the spectra show that the interaction between the extract and Al happened through the mentioned functional groups. The missed groups explained the adsorption procedure of JRE on the Al outer surface [53]. The functional groups have coordinated with $\mathrm{Al}^{3+}$ leads to the formation of $\mathrm{Al}^{3+}$ inhibitor complex that improves the inhibitive influence of the Al metal.

\subsection{X-Ray photoelectron spectroscopy (XPS) examination.}

XPS examination provides profound knowledge about the binding energies of the interference among Juglans Regia extract and the Al outer surface. The XPS peaks of Al 2p, $\mathrm{Cl} 2 \mathrm{p}, \mathrm{C} 1 \mathrm{~s}$ and $\mathrm{O} 1 \mathrm{~s}$ acquired for $\mathrm{Al}$ surface after dipping in $2 \mathrm{M} \mathrm{HCl}$ with the optimal concentration of $300 \mathrm{ppm}$ of (JRE) following deconvolution by curvature fitting were appeared in Fig. 14. The Al 2p spectrum gave one top situated at binding energy (BE) of $74.4 \mathrm{eV}$. This top corresponds to $\mathrm{Al} 2 \mathrm{O} 3$ as appeared in (Fig. 14a). The $\mathrm{Cl} 2 \mathrm{p}$ is deconvoluted into two tops situated at $197.9 \mathrm{eV}$ related to $\mathrm{Cl} 2 \mathrm{p} 3 / 2$ and $199.3 \mathrm{eV}$ refers to $\mathrm{Cl} 2 \mathrm{p} 1 / 2$ (Fig. 14b) [54]. The $\mathrm{C} 1 \mathrm{~s}$ peaks illustrated three tops situated at 284.4, 285.9, $288.6 \mathrm{eV}$ (Fig. 14c).

The biggest top at 284.4 can be related to the $\mathrm{C}-\mathrm{C}$ bond of aromatic compounds. Also, the tops situated at 285.9, 288.6 eV are credited because of the $\mathrm{C}=\mathrm{O}$ and $\mathrm{COO}$ bonds, separately [55]. The top situated at $288.6 \mathrm{eV}$ which associated with $\mathrm{C}=\mathrm{O}$ illustrates that (JRE) particles 
have been adsorbed [56]. The graph of O 1s (Fig.14d) is deconvoluted into three tops, the top at $531.08 \mathrm{eV}$ that appointed to $\mathrm{Al}_{2} \mathrm{O}_{3}$, the second one at $532.16 \mathrm{eV}$ which related to $\mathrm{C}-\mathrm{O}$ bond [57], while the third top situated at $532.63 \mathrm{eV}$ binding energy which identified with the C-O-C aromatic bonds [58]. Finally, the XPS results demonstrated that the inhibitive form shaped on the $\mathrm{Al}$ surface includes $\mathrm{C}$ and $\mathrm{O}$ atoms in different molecules that demonstrate the arrangement of the formed film of the examined(JRE).
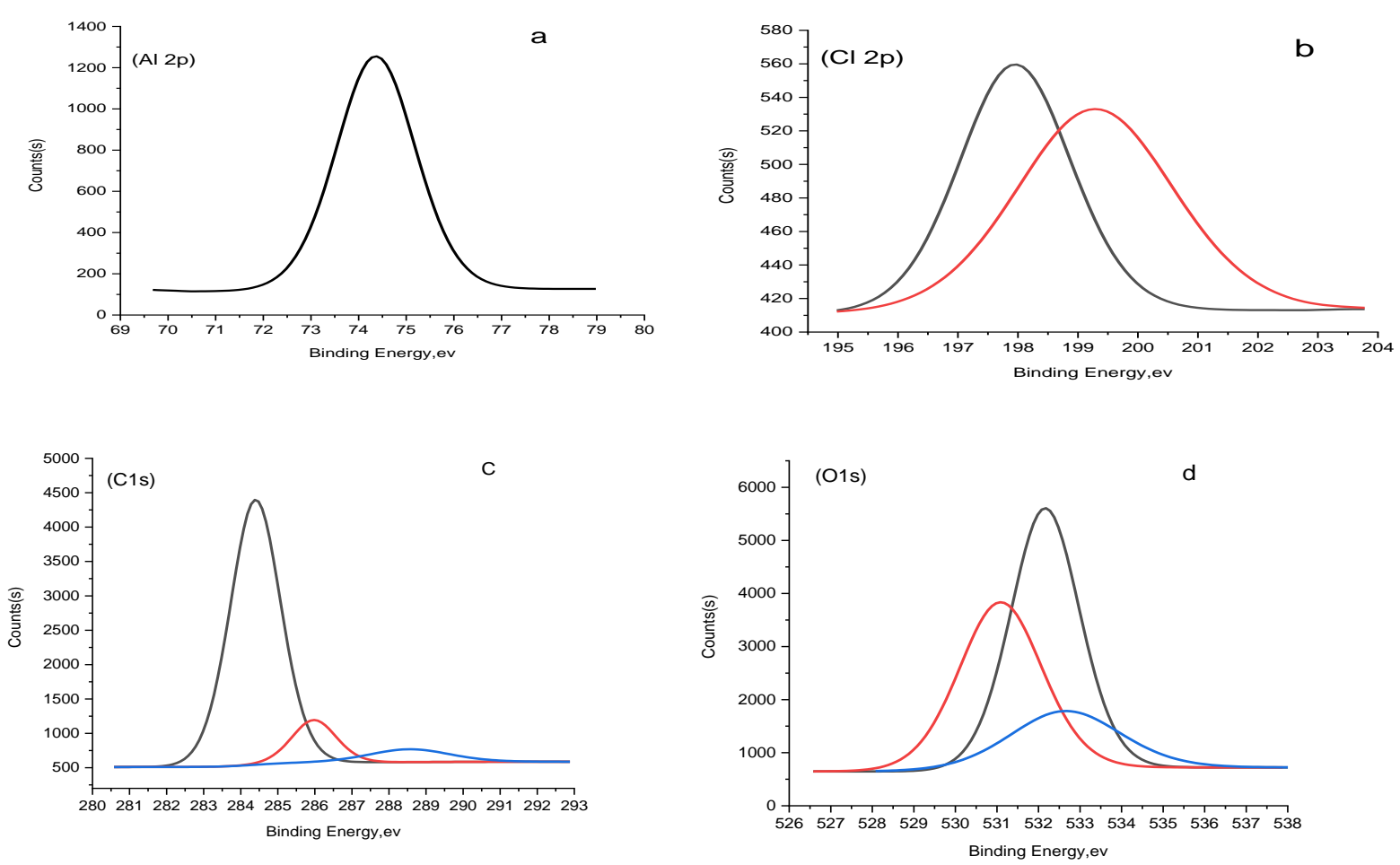

Figure 14. XPS graphs of (a) $\mathrm{Al} \mathrm{2p,} \mathrm{(b)} \mathrm{Cl} 2 \mathrm{p}$, (c) $\mathrm{C} 1 \mathrm{~s}$, and (d) $\mathrm{O} 1 \mathrm{~s}$, for $\mathrm{Al}$ in $2 \mathrm{M} \mathrm{HCl}$.

\subsection{Inhibitive Mechanism.}

Consumption happens by major reactions: oxidation reaction and $\mathrm{H}_{2}$ evolution. The inhibitive technique of aluminum in acidic medium is commonly identified with an adsorption procedure of the particles onto the $\mathrm{Al}$ surface. Along these lines, the organic particles that exist in the extract impeded dissolution most likely by diminishing both reactions. There are various variables influencing the inhibiting productivity of the inhibitor involving metal type, molecular volume, destructive medium, the electronic construction, adsorption positions, and substance characteristic, and method of interference by the accompanying relations: $\mathrm{Cl}$ ions are adsorbed on the Al positively charged outer surface converted it to negative sign, then the protonated compounds of JRE were adsorbed on the negative surface. From our obtained outcomes, the adsorption of these particles of JRE happens, diminishing the dissolution reaction. The adsorption is accepted to happen through the anodic sites likely happened through long $\pi$-electrons of aromatic rings in JRE extract. XPS examination indicated that the particles that exist in JRE were adsorbed on the Al outer surface, affirming its inhibitive ability [59].

\section{Conclusions}

The outcomes got from all techniques demonstrated that the inhibitive activity rises with elevating the JRE amounts and diminishes with expanding the temperature (physical 
adsorption). Expanding the dose of the JRE, diminishing the double layer capacitances $\left(\mathrm{C}_{\mathrm{dl}}\right)$ and expanding the polarization resistance $(\mathrm{Rp})$. he adsorption of plant extract particles on the $\mathrm{Al}$ surface is ascribed to Langmuir isotherm. Tafel polarization results demonstrate that JRE appears as mixed type inhibitor. The inhibition efficiencies examined by ML, HE, PP, EFM and EIS strategies are in sensibly acceptable agreement. AFM micrographs show that this extract is adsorbed on Al surface shaping a defensive film. FTIR investigation of the extract and consumption product indicated the functional groups that have coordinated with $\mathrm{Al}^{3+}$. The XPS examination affirmed the development of a defensive layer of JRE extract on aluminum surface.

\section{Funding}

This research received no external funding.

\section{Acknowledgments}

All our gratitude to the anonymous referees for their careful reading of the manuscript and valuable comments which helped in shaping this paper to the present form. We thank all laboratory staff of corrosion chemistry from the University of Mansoura (Egypt) for their kind cooperation.

\section{Conflicts of Interest}

The authors declare no conflict of interest.

\section{References}

1. Ali, A.I.; Foaud, N. Inhibition of aluminum corrosion in hydrochloric acid solution using black mulberry extract. Journal of Materials and Environmental Science 2012, 3, 917-924.

2. Raghavendra, N. Green Compounds to Attenuate Aluminum Corrosion in $\mathrm{HCl}$ Activation: A Necessity Review. Chemistry Africa 2020, 3, 21-34, https://doi.org/10.1007/s42250-019-00114-6.

3. Onukwuli, O.D.; Ezeugo, J.O. Plant extract as biodegradable inhibitor, for zinc in dilute solution of sulphuric acid. World Scientific News 2018, 109, 195-210.

4. Raghavendra, N.; Hublikar, L.V.; Patil, S.M.; Ganiger, P.J.; Bhinge, A.S. Efficiency of sapota leaf extract against aluminium corrosion in a $3 \mathrm{M}$ sodium hydroxide hostile fluid atmosphere: a green and sustainable approach. Bulletin of Materials Science 2019, 42, https://doi.org/10.1007/s12034-019-1922-1.

5. Boumhara, K.; Harhar, H.; Tabyaoui, M.; Bellaouchou, A.; Guenbour, A.; Zarrouk, A. Corrosion Inhibition of Mild Steel in 0.5 M H2SO4 Solution by Artemisia herba-alba Oil. Journal of Bio- and Tribo-Corrosion 2018, 5, https://doi.org/10.1007/s40735-018-0202-8.

6. Oguzie, E.E.; Enenebeaku, C.K.; Akalezi, C.O.; Okoro, S.C.; Ayuk, A.A.; Ejike, E.N. Adsorption and corrosion-inhibiting effect of Dacryodis edulis extract on low-carbon-steel corrosion in acidic media. Journal of Colloid and Interface Science 2010, 349, 283-292, https://doi.org/10.1016/j.jcis.2010.05.027.

7. Oguzie, E.E.; Onuchukwu, A.I.; Okafor, P.C.; Ebenso, E.E. Corrosion inhibition and adsorption behaviour of Ocimum basilicum extract on aluminium. Pigment \& Resin Technology 2006, 35, 63-70, https://doi.org/10.1108/03699420610652340.

8. Okafor, P.C.; Ikpi, M.E.; Uwah, I.E.; Ebenso, E.E.; Ekpe, U.J.; Umoren, S.A. Inhibitory action of Phyllanthus amarus extracts on the corrosion of mild steel in acidic media. Corrosion Science 2008, 50, 2310-2317, https://doi.org/10.1016/j.corsci.2008.05.009.

9. Njoku, C.N.; Bai, W.; Arukalam, I.O.; Yang, L.; Hou, B.; Njoku, D.I.; Li, Y. Epoxy-based smart coating with self-repairing polyurea-formaldehyde microcapsules for anticorrosion protection of aluminum alloy AA2024. Journal of Coatings Technology and Research 2020, 17, 797-813, https://doi.org/10.1007/s11998-020-003343.

10. Fouda, A.S.; Abousalem, A.S.; El-Ewady, G.Y. Mitigation of corrosion of carbon steel in acidic solutions using an aqueous extract of Tilia cordata as green corrosion inhibitor. International Journal of Industrial Chemistry 2017, 8, 61-73, https://doi.org/10.1007/s40090-016-0102-z. 
11. Fouda, A.S.; Abdallah, M.; Eissa, M. Corrosion inhibition of Aluminum in 1 M phosphoric acid solutions using some Chalcones derivatives and synergistic action with halide ions. African Journal of Pure and Applied Chemistry 2013, 7, 394-404.

12. Khadraoui, A.; Khelifa, A.; Hamitouche, H.; Mehdaoui, R. Inhibitive effect by extract of Mentha rotundifolia leaves on the corrosion of steel in $1 \mathrm{M} \mathrm{HCl}$ solution. Research on Chemical Intermediates 2014, 40, 961-972, https://doi.org/10.1007/s11164-012-1014-y.

13. Kasuga, B.; Park, E.; Machunda, R. Inhibition of Aluminium Corrosion Using Carica papaya Leaves Extract in Sulphuric Acid. Journal of Minerals and Materials Characterization and Engineering 2018, 06, 1-14, https://doi.org/10.4236/jmmce.2018.61001.

14. Fouda, A.S.; El-Awady, G.Y.; El Behairy, W.T. Prosopis juliflora Plant Extract as Potential Corrosion Inhibitor for Low-Carbon Steel in $1 \mathrm{M} \mathrm{HCl} \mathrm{Solution.} \mathrm{Journal} \mathrm{of} \mathrm{Bio-} \mathrm{and} \mathrm{Tribo-Corrosion} \mathrm{2017,} \mathrm{4,}$ https://doi.org/10.1007/s40735-017-0124-X.

15. Elabbasy, H.M.; Zidan, S.M.; Fouda, A.S. Inhibitive behavior of ambrosia maritima extract as aneco-friendly corrosion inhibitor for carbon steel in $1 \mathrm{M} \mathrm{HCl}$. Zastita Materijala 2019, 60, 129-146, https://doi.org/10.5937/zasmat1902129E.

16. Shainy, K.M.; Rugmini Ammal, P.; Unni, K.N.; Benjamin, S.; Joseph, A. Surface Interaction and Corrosion Inhibition of Mild Steel in Hydrochloric Acid Using Pyoverdine, an Eco-Friendly Bio-molecule. Journal of Bio- and Tribo-Corrosion 2016, 2, https://doi.org/10.1007/s40735-016-0050-3.

17. Raghavendra, N.; Bhat, J.I. Natural Products for Material Protection: An Interesting and Efficacious Anticorrosive Property of Dry Arecanut Seed Extract at Electrode (Aluminum)-Electrolyte (Hydrochloric Acid) Interface. Journal of Bio- and Tribo-Corrosion 2016, 2, https://doi.org/10.1007/s40735-016-0051-2.

18. Tawfik, S.M.; Negm, N.A. Vanillin-derived non-ionic surfactants as green corrosion inhibitors for carbon steel in acidic environments. Research on Chemical Intermediates 2016, 42, 3579-3607, https://doi.org/10.1007/s11164-015-2233-9.

19. Chaubey, N.; Singh, V.K.; Quraishi, M.A. Electrochemical approach of Kalmegh leaf extract on the corrosion behavior of aluminium alloy in alkaline solution. International Journal of Industrial Chemistry 2017, 8, 7582, https://doi.org/10.1007/s40090-016-0103-y.

20. Fouda, A.S.; Emam, A.; Refat, R.; Nageeb, M. Cascabela Thevetia Plant Extract as Corrosion Inhibitor for Carbon Steel in Polluted Sodium Chloride Solution. J. Anal Pharm Res 2017, 6, https://doi.org/10.15406/japlr.2017.06.00168.

21. Fouda, A.S.; Rashwan, S.; Kamel, M.M.; Arman, N.M. Adsorption and Inhibition Behavior of Avicennia Marina for Zn Metal in Hydrochloric Acid Solution. International Journal of Electrochemical Science 2017, 12, 11789-11804, https://doi.org/10.20964/2017.12.95.

22. Arumugam, P.; Subbiah, S.; Kannusamy, K. Albizia lebbeck seed extract as effective corrosion inhibitor for Mild steel in acid medium, Bio interface Res. Appl.Chem. 2013, 3, 498-506.

23. Arumugam P.; Subbiah S.; Kannusamy K. Corrosion control of mild steel in 1.0N Hydrochloric acid medium using Pyrus pyrifolia fruit peel extract, Biointerface Res. Appl.Chem. 2014, 4, 685-693.

24. Bennacer, A.; Cherif, H.S. Contribution to the Ethnobotanical, Phytochemical, Antimicrobial and Antioxidant Study of the Leaves' Aqueous Extract of the Common Walnut "Juglans regia L.". International Journal of Pharmacology, Phytochemistry and Ethnomedicine 2017, 7, 41-52, https://doi.org/10.18052/www.scipress.com/IJPPE.7.41.

25. Verma, R.S.; Padalia, R.C.; Chauhan, A.; Thul, S.T. Phytochemical analysis of the leaf volatile oil of walnut tree (Juglans regia L.) from western Himalaya. Industrial Crops and Products 2013, 42, 195-201, https://doi.org/10.1016/j.indcrop.2012.05.032.

26. Shalabi, K.; Abdallah, Y.M.; Fouda, A.S. Corrosion inhibition of aluminum in $0.5 \mathrm{M} \mathrm{HCl}$ solutions containing phenyl sulfonylacetophenoneazo derivatives. Research on Chemical Intermediates 2015, 41, 4687-4711, https://doi.org/10.1007/s11164-014-1561-5.

27. Wasim, M.; Shoaib, S.; Mubarak, N.M.; Inamuddin; Asiri, A.M. Factors influencing corrosion of metal pipes in soils. Environmental Chemistry Letters 2018, 16, 861-879, https://doi.org/10.1007/s10311-018-0731-x.

28. Augustin, O.; Silvère, D.N.g.Y.; Williams, I.B.I.; Coulibaly Nagnonta, H.; Albert, T. Copper Corrosion Inhibition by Cefpodoxime Drug in 1M Nitric Acid : Experimental and DFT approaches. International Journal of Innovation and Applied Studies 2018, 24, 1299-1311.

29. Appa Rao, B.V.; Narsihma Reddy, M. Formation, characterization and corrosion protection efficiency of selfassembled 1-octadecyl-1H-imidazole films on copper for corrosion protection. Arabian Journal of Chemistry 2017, 10, S3270-S3283, https://doi.org/10.1016/j.arabjc.2013.12.026.

30. Abd El-Lateef, H.M. Synergistic effect of polyethylene glycols and rare earth Ce4+ on the corrosion inhibition of carbon steel in sulfuric acid solution: electrochemical, computational, and surface morphology studies. Research on Chemical Intermediates 2016, 42, 3219-3240, https://doi.org/10.1007/s11164-015-2207-y.

31. Abdallah, M.; Kamar, E.M.; Eid, S.; El-Etre, A.Y. Animal glue as green inhibitor for corrosion of aluminum and aluminum-silicon alloys in sodium hydroxide solutions. Journal of Molecular Liquids 2016, 220, 755761, https://doi.org/10.1016/j.molliq.2016.04.062. 
32. Soltani, N.; Tavakkoli, N.; Attaran, A.; Karimi, B.; Khayatkashani, M. Inhibitory effect of Pistacia khinjuk aerial part extract for carbon steel corrosion in sulfuric acid and hydrochloric acid solutions. Chemical Papers 2020, 74, 1799-1815, https://doi.org/10.1007/s11696-019-01026-y.

33. Morales, A.; Piamba, O.; Olaya, J. The Corrosion Resistance of Aluminum-Bronze Coatings as a Function of Gas Pressure Used in the Thermal Spraying Process. Coatings 2019, 9, https://doi.org/10.3390/coatings9080507.

34. Fouda, A.S.; Abd El-Maksoud, S.A.; El-Hossiany, A.; Ibrahim, A. Corrosion Protection of Stainless Steel 201 in Acidic Media using Novel Hydrazine Derivatives as Corrosion Inhibitors. Int. J. Electrochem. Sci. 2019, 14, 2187-2207, https://doi.org/10.20964/2019.03.15.

35. Bedair, M.A.; El-Sabbah, M.M.B.; Fouda, A.S.; Elaryian, H.M. Synthesis, electrochemical and quantum chemical studies of some prepared surfactants based on azodye and Schiff base as corrosion inhibitors for steel in acid medium. Corrosion Science 2017, 128, 54-72, https://doi.org/10.1016/j.corsci.2017.09.016.

36. Fouda, A.S.; Killa, H.M.; Farouk, A.; Salem, A.M. CalicotomeExtract as a Friendly Corrosion Inhibitor forCarbon Steel in Polluted NaClSolution: Chemical and Electrochemical Studies. Egyptian Journal of Chemistry 2019, 62, 1879-1894, https://doi.org/10.21608/EJCHEM.2019.7656.1649.

37. Fouda, A.S.; Abdel Haleem, E. Berry Leaves Extract as Green Effective Corrosion Inhibitor for Cu in Nitric Acid Solutions. Surface Engineering and Applied Electrochemistry 2018, 54, 498-507, https://doi.org/10.3103/S1068375518050034.

38. Li, X.; Deng, S.; Li, N.; Xie, X. Inhibition effect of bamboo leaves extract on cold rolled steel in $\mathrm{Cl} 3 \mathrm{CCOOH}$ solution. Journal of Materials Research and Technology 2017, 6, 158-170, https://doi.org/10.1016/j.jmrt.2016.09.002.

39. Hsissou, R.; Abbout, S.; Berisha, A.; Berradi, M.; Assouag, M.; Hajjaji, N.; Elharfi, A. Experimental, DFT and molecular dynamics simulation on the inhibition performance of the DGDCBA epoxy polymer against the corrosion of the E24 carbon steel in $1.0 \mathrm{M} \mathrm{HCl}$ solution. Journal of Molecular Structure 2019, 1182, 340351, https://doi.org/10.1016/j.molstruc.2018.12.030.

40. Fouda, A.S.; Migahed, M.A.; Atia, A.A.; Mousa, I.M. Corrosion Inhibition and Adsorption Behavior of Some Cationic Surfactants on Carbon Steel in Hydrochloric Acid Solution. Journal of Bio- and Tribo-Corrosion 2016, 2, https://doi.org/10.1007/s40735-016-0052-1.

41. Fouda, A.S.; Mohamed, F.S.; El-Sherbeni, M.W. Corrosion Inhibition of Aluminum-Silicon Alloy in Hydrochloric Acid Solutions Using Carbamidic Thioanhydride Derivatives. Journal of Bio- and TriboCorrosion 2016, 2, https://doi.org/10.1007/s40735-016-0039-y.

42. Fouda, A.S.; El-Ewady, G.; Ali, A.H. Modazar as promising corrosion inhibitor of carbon steel in hydrochloric acid solution. Green Chemistry Letters and Reviews 2017, 10, 88-100, https://doi.org/10.1080/17518253.2017.1299228.

43. Fouda, A.S.; Ismael, M.A.; Abo Shahba, R.M.; Kamel, L.A.; El-Nagggar, A.A. Corrosion Inhibition of Copper and $\alpha$-Brass in $1 \mathrm{M}$ HNO3 Solution using New arylpyrimido [5, 4-c] quinoline-2,4-dione derivative. Int. J. Electrochem.Sci. 2017, 12, 3361-3384, https://doi.org/10.20964/2017.04.57.

44. Eldesoky, A. Green Corrosion Electrochemistry: Cheilocostus Speciosus Extract (CSE) Investigated Electroanalytically as a Potential Green Corrosion Inhibitor for Copper within Acidic Solution. International Journal of emerging trends in engineering and development (IJETED) 2017, 1.

45. Baymou, Y.; Bidi, H.; Ebn Touhami, M.; Allam, M.; Rkayae, M.; Belakhmima, R.A. Corrosion Protection for Cast Iron in Sulfamic Acid Solutions and Studies of the Cooperative Effect Between Cationic Surfactant and Acid Counterions. Journal of Bio- and Tribo-Corrosion 2018, 4, https://doi.org/10.1007/s40735-018-0127-2.

46. Nadi, I.; Belattmania, Z.; Sabour, B.; Reani, A.; Sahibed-dine, A.; Jama, C.; Bentiss, F. Sargassum muticum extract based on alginate biopolymer as a new efficient biological corrosion inhibitor for carbon steel in hydrochloric acid pickling environment: Gravimetric, electrochemical and surface studies. International Journal of Biological Macromolecules 2019, 141, 137-149, https://doi.org/10.1016/j.ijbiomac.2019.08.253.

47. Ibrahim, M.B.; Sulaiman, Z.; Usman, B.; Ibrahim, M.A. Effect of Henna Leaves on the Corrosion Inhibition of Tin in Acidic and Alkaline Media. World Journal of Applied Chemistry 2019, 4, 54-51, https://doi.org/10.11648/j.wjac.20190404.11.

48. Fouda, A.S.; Abdel Nazeer, A.; El behairy, W.T. Assessment of Begonia Extract as New Eco-friendly Inhibitor for Low-Carbon-Steel Corrosion in Acidic Environment. Journal of Bio- and Tribo-Corrosion 2017, 4, https://doi.org/10.1007/s40735-017-0122-z.

49. Fouda, A.S.; Megahed, H.E.; Fouad, N.; Elbahrawi, N.M. Corrosion Inhibition of Carbon Steel in $1 \mathrm{M}$ Hydrochloric Acid Solution by Aqueous Extract of Thevetia peruviana. Journal of Bio- and Tribo-Corrosion 2016, 2, https://doi.org/10.1007/s40735-016-0046-Z.

50. Zhang, S.; Hou, L.; Du, H.; Wei, H.; Liu, B.; Wei, Y. A study on the interaction between chloride ions and $\mathrm{CO} 2$ towards carbon steel corrosion. Corrosion Science 2020, 167, https://doi.org/10.1016/j.corsci.2020.108531.

51. Devi, P.N.; Sathiyabama, J.; Rajendran, S. Study of surface morphology and inhibition efficiency of mild steel in simulated concrete pore solution by lactic acid-Zn2+ system. International Journal of Corrosion and Scale Inhibition 2017, 6, 18-31, https://doi.org/10.17675/2305-6894-2017-6-1-2. 
52. Al-Nami, S. Calotropis Procera Extract as Corrosion Inhibitor for Copper in Nitric Acidic Environment. International Journal of Electrochemical Science 2019, 14, 6902-6919.

53. Muthukrishnan, P.; Jeyaprabha, B.; Prakash, P. Adsorption and corrosion inhibiting behavior of Lannea coromandelica leaf extract on mild steel corrosion. Arabian Journal of Chemistry 2017, 10, S2343-S2354, https://doi.org/10.1016/j.arabjc.2013.08.011.

54. Zhang, L.; He, Y.; Zhou, Y.; Yang, R.; Yang, Q.; Qing, D.; Niu, Q. A novel imidazoline derivative as corrosion inhibitor for P110 carbon steel in hydrochloric acid environment. Petroleum 2015, 1, 237-243, https://doi.org/10.1016/j.petlm.2015.10.007.

55. Maxime, C.; Florent, R.; Nadine, A.; Michel, T.; Christophe, R.; Mounim, L. Anti-corrosive behavior of ethanolic extract of banana peel against acidic media and their thermodynamic studies. Electrochimica Acta 2014, 131.

56. Yadav, M.; Kumar, S.; Sinha, R.R.; Bahadur, I.; Ebenso, E.E. New pyrimidine derivatives as efficient organic inhibitors on mild steel corrosion in acidic medium: Electrochemical, SEM, EDX, AFM and DFT studies. Journal of Molecular Liquids 2015, 211, 135-145, https://doi.org/10.1016/j.molliq.2015.06.063.

57. Sadowski, R.; Wach, A.; Buchalska, M.; Kuśtrowski, P.; Macyk, W. Photosensitized TiO2 films on polymers - Titania-polymer interactions and visible light induced photoactivity. Applied Surface Science 2019, 475, 710-719, https://doi.org/10.1016/j.apsusc.2018.12.286.

58. Fouda, A.S.; Zaki, E.G.; Khalifa, M.M.A. Some New Nonionic Surfactants Based on Propane Tricarboxylic Acid as Corrosion Inhibitors for Low Carbon Steel in Hydrochloric Acid Solutions. Journal of Bio- and TriboCorrosion 2019, 5, https://doi.org/10.1007/s40735-019-0223-z.

59. Habibiyan, A.; Ramezanzadeh, B.; Mahdavian, M.; Kasaeian, M. Facile size and chemistry-controlled synthesis of mussel-inspired bio-polymers based on Polydopamine Nanospheres: Application as eco-friendly corrosion inhibitors for mild steel against aqueous acidic solution. Journal of Molecular Liquids 2020, 298, https://doi.org/10.1016/j.molliq.2019.111974. 